\title{
Prevalence of Sports Related Oral Injuries and Use of Mouth-Guards: A Mini Review
}

\author{
Ajay Jain ${ }^{1 *}$ and Ugrappa Sridevi ${ }^{2}$ \\ ${ }^{1}$ Department of Prosthodontics, AIMST Dental Institute, Malaysia \\ ${ }^{2}$ Department of Oral Medicine \& Radiology, AIMST Dental Institute, Malaysia
}

Received: June 19, 2018; Published: June 22, 2018

*Corresponding author: Ajay Jain, Associate Professor, Faculty of Dentistry, AIMST Dental Institute, AIMST University, Kedah, Malaysia

Abstract

Oral injuries can cause disfigurement after healing to sufferer that might affect the athlete's quality of life. It is important that athletes should be aware of how they are at risk for dental and soft-tissue injuries and prevention of such injuries can be achieved if they utilized mouthguards during sport activities. This article reviews the prevalence of sports related oral injuries and importance of mouth-guards in preventing these injuries.

\section{Introduction}

People engaged in frivolous and competitive sports activities for both physical and psychological well-being. Unfortunately, participating in sports activities is at risk of sustaining trauma to the oral hard and/or soft tissues such as chipped, luxated or avulsed teeth, maxillary or mandibular fractures, lip lacerations and other injuries to the gingivae, tongue or mucosa [1]. Hard and soft-tissue injuries are common; not only to high-risk contact sports such as boxing, hockey, rugby and lacrosse, but also to other, less obviously hazardous sports (for instance basketball and baseball) and non-contact activities (for instance gymnastics and in-line skating) [2]. Study performed among Nigerian young adult athletes, contact sports accounted for $78.5 \%$ of the oral injuries, while only $21.5 \%$ were resulted from non-contact sports [3]. Athletes participating in martial arts which are one of the contact sports suffered the highest injury rate $(41.5 \%)$, than athletes participating in ball sports (17.2\%) and other non-contact sports (15.2\%) [4].

Sports-related dental injuries account for $13 \%$ to $39 \%$ of all trauma cases in Germany [5]. The prevalence of dental trauma among Pan American games athletes was $49.6 \%$, where $63.6 \%$ of them were related to activities during training or competition [6]. In the Czech Republic, the most frequent causes of injured permanent teeth in patients older than 11 years were sport activities [7]. The risk of oral injuries during performing sports and exercise activities can be reduced markedly by using mouth guards [8]. It offer protection by untying the cheeks and lips from the teeth, making users less vulnerable to soft-tissue laceration and preventing opposing arches from traumatic contact and these protective devices provide a resilient, protective surface to distribute and dissipate transmitted forces on impact.

Studies have been done on wearing mouth guards and occurrence of dental injuries. Basketball players who use mouth guards had significantly lower rates of dental injuries and dentist referrals [9]. A Nigerian study also showed that prevalence of orofacial injuries was significantly lower while wearing a mouth guard [10]. A survey in Switzerland, Germany and France found only one individual among all of squash players who experienced dental traumas wore a mouth guard [11]. The importance of utilizing mouth guard was found in one Turkish study where $13.2 \%$ of university athletes had suffered from one or more form of oral injury while not wearing mouth guards [12].

\section{References}

1. Dale RA (2000) Dentoalveolar trauma. Emerg Med Clin North Am 18(3): 521-538.

2. ADA Council on Access, Prevention and Interprofessional Relations; ADA Council on Scientific Affairs. (2006) Using mouthguards to reduce the incidence and severity of sports-related oral injuries. J Am Dent Assoc 137(12): 1712-1720.

3. Onyeaso CO, Adegbesan OA (2003) Oro-facial injury and mouthguard usage by athletes in Nigeria. Int Dent J 53(4): 231-236.

4. Oo MT, Razali R (2012) Sport-related oral injuries and mouthguard use among athletes in Kelantan, Malaysia. Arch OrofacSci 7(1): 21-27.

5. Mischkowski RA, Siessegger M, Zoller JE (1999) Mouth guard protection for prevention of athletic injuries to teeth, mouth and jaw. SportverletzSportschaden 13(3): 65-67. 
6. Andrade RA, Evans PL, Almeida AL, da Silva Jde J, Guedes Am, et al. (2010) Prevalence of dental trauma in Pan American games athletes. Dent Traumatol 26(3): 248-253.

7. Hecova H, Tzigkounakis V, Merglova V, Netolicky J (2010) A retrospective study of 889 injured permanent teeth. Dent Traumatol 26(6): 466-475.

8. Woodmansey KF (1999) Athletic mouth guards prevent orofacial injuries: a review. Gen Dent 47(1): 64-69.

9. Labella CR, Smith BW, Sigurdsson A (2002) Effect of mouthguards on dental injuries and concussions in college basketball. Med Sci Sport Exerc 34(1): 41-44.

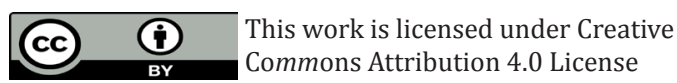

Submission Link: https://biomedres.us/submit-manuscript.php
10. Onyeaso CO (2004) Oro-facial trauma in amateur secondary school footballers in Ibadan, Nigerian: a study of mouthguards. Odontostomatol Trop 27(105): 32-36.

11. Persic R, Pohl Y, Filippi A (2006) Dental squash injuries-a survey among players and coaches in Switzerland, Germany and France. Dent Traumatol 22(5): 231-236.

12. Cetinbas T, Sonmez H (2006) Mouthguard utilization rates during sport activities in Ankara, Turkey. Dent Traumatol 22(3): 127-132.

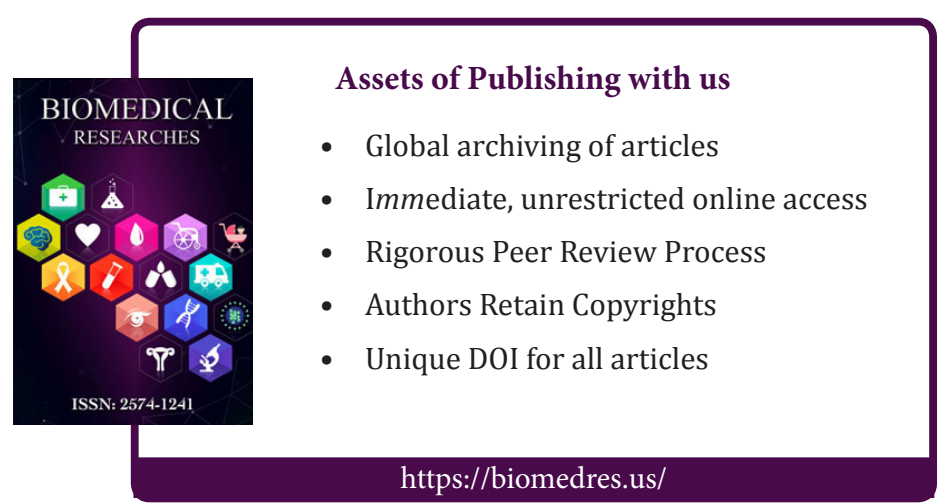

